Book Review

ISSN: 2162-3104 Print/ ISSN: 2166-3750 Online

Volume 6, Issue 3 (2016), pp. 825-827

(C) Journal of International Students

http://jistudents.org/

\title{
International Student Handbook
}

The College Board. (2015). 2016 international student handbook (29 $9^{\text {th }}$ ed.). New York: NY: Author.

Reviewed by: Nara M. Martirosyan, Sam Houston State University (USA)

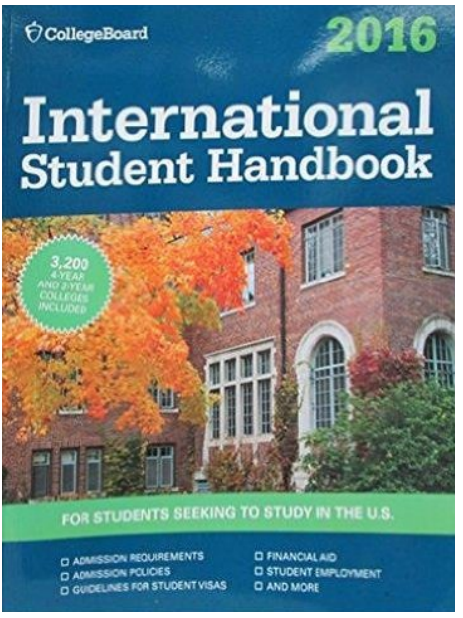

For the past 15 years, the number of international students in American higher education has increased steadily (Institute of International Education, 2014). According to the Institute of International Education (2014), "The United States hosts more of the world's 4.5 million globally mobile college and university students than any other country in the world" (para. 1). As the number of international students in American higher education continues to grow every year, there is need for up to date information on U.S. host institutions, their programs and admission requirements, as well as the various procedures pertaining to international student admission. The 29th edition of International Student Handbook published by the College Board (2015) is the most recent guide for prospective international students interested in postsecondary education in the United States. It consists of three parts, which are briefly reviewed below.

Part I of the Handbook offers essential information for prospective international students to consider when in the process of searching and/or applying for admission in an American institution. It advises the students to plan for study in the U.S. at least two years in advance from the estimated time of admission, and presents a set of estimated deadlines to follow. The organization of the U.S. education system, types of institutions, degrees, course credit system, transcripts evaluation, along with information on accreditation, college costs and financial aid are also presented in this section. An article by Judy Irwin included in this section discusses the educational opportunities available through community colleges, and lists a number of benefits for enrolling in community colleges (e.g., low tuition 
cost, the availability of English language programs, the possibility of transferring to four-year colleges after studying in community colleges, etc.). Another chapter in this section provides detailed advice to prospective undergraduate international applicants. It guides the future applicant through important decision making steps, starting from choosing a college and finishing with a complete application package and all its required documents. Information on various tests that are used for admission purposes in U.S. institutions is also explained. Finally, Part I walks the prospective international student through actions that should be taken after receiving an admission confirmation from a U.S. institution. Important information on visa regulations is provided along with a pre-departure checklist guide and glossary of terms used in U.S. higher education.

Part II includes informational tables of over 3,200 undergraduate institutions in the United States. These tables provide information on degrees, undergraduate enrollment, required tests and their minimum scores, application deadlines, student services, housing, academic year cost, and financial aid opportunities. Institutions are listed alphabetically by state, and readers are guided on how to use the information tables.

Part III provides lists and indexes of various institutional information per college/university including: overall and international undergraduate student enrollment, financial aid, conditional admission opportunities based on English language proficiency, SAT Subject Tests ${ }^{\mathrm{TM}}$ requirements, credit/placement for International Baccalaureate and for Advancement Placement, availability of ESL programs on campus, special housing opportunities specifically for international students, and college type. An alphabetical list containing contact information of each college/university is also included in Part III. Readers are provided with the mailing address, telephone number, website address and fax number (when available) of each college. Finally, this part provides contact information on Education USA Advising Centers abroad where prospective international students can visit in their own country, and obtain more information about studying in the United States.

The $29^{\text {th }}$ edition of International Student Handbook is a comprehensive informational resource for any prospective student interested in obtaining an undergraduate education in the United States. Current international students who may be interested in transferring from their current institution to another U.S. institution will also find this guide useful. Beyond students, the information is also valuable to study abroad/exchange program coordinators in foreign countries, as well as counselors and administrators involved in international student recruitment and admission in American colleges and universities.

As stated in the book, "the process of researching, selecting and applying to colleges and universities in the United States is difficult and 
time consuming” (p. 1), and therefore, having access to this handbook would make the process smoother. Information on more than 3,200 American colleges and universities included in the handbook covers almost every essential area (e.g., tuition cost, housing availability, financial aid opportunities, etc.) where the prospective and current international students might have questions. The author also suggests exploring international.collegeboard.org when searching for colleges, registering for SAT tests, and attaining learning materials for exam preparation. The handbook is user-friendly, easy to read and locate specific information on particular areas of interest related to studying in the United States.

\section{REFERENCE}

Institute of International Education. (2014). Open Doors 2014: International students in the United States and Study Abroad by American Students are at all-time high. Retrieved from http://www.iie.org/Who-We-Are/News-and-Events/PressCenter/Press-Releases/2014/2014-11-17-Open-Doors-Data 